\title{
The Role of Kenya's Taifa Leo Newspaper in Enhencing Learners' Abilities in Kiswahili Language Proficience
}

\author{
Mukhwana A. Sirengo ${ }^{1}$, Mukhwana C. Sirengo ${ }^{1}$ \\ ${ }^{1}$ Department of Kiswahili, University of Nairobi, P.O Box 30197, 00100 Nairobi.
}

*Corresponding Author: Mukhwana A. Sirengo, Mukhwana C. Sirengo, Department of Kiswahili, University of Nairobi, P.O Box 30197, 00100 Nairobi.

\begin{abstract}
The central theme of the present paper is that the use of Taifa Leo newspaper in instruction in Kenya helps in improving students' media literacy skills besides giving them knowledge on how the use of newspaper language can stand out as a register of its own. The main objective of the study was to investigate the extent to which Taifa Leo newspaper in Kenya is used for Kiswahili language instruction of high school students by focusing on the contents and texts of Taifa Leo newspaper. Besides reading and analysing the Taifa Leo newspaper, the research also used questionnaires as well as telephone interviews. The findings of the research bring out the fact that Taifa Leo newspaper is an important instructional tool in Kenya, but that that needs to be used with lots of care.
\end{abstract}

Keywords: Newspaper, Instructional material, Taifa Leo, Kiswahili

\section{INTRODUCTION}

Education plays a significant role in the development of any country (Cabansag 2011, Veronis 2006). In Kenya, the National Goals of Education include fostering of nationalism, patriotism and promotion of national unity, promotion of social, economic, technological and industrial needs for national development, promotion of individual development and self fulfillment, promotion of sound moral and religious values, promotion of social equality and responsibility, promotion of respect for and development of Kenya's rich and varied cultures, promotion of international consciousness and fostering of positive attitude towards other nations as well as promoting positive attitudes towards good health and environmental protection. The literacy rate of the Kenyan population of 15 years and above who can read and write was at $87.4 \%$ according to the reports by the CIA World Fact-book (2015). $90.6 \%$ of the population comprised of males and the females' percentage estimated at $84.2 \%$.

Despite the above indicated rates, education in Kenya faces several challenges including inadequate infrastructure and shortage of permanent classrooms in primary schools. Lack of clear legal guidelines on the implementation of inclusive education and non-formal education programs, low transition rates from primary education to secondary schools and from secondary schools to higher institutions of learning as well as employment, outdated curricula for technical training and vocational education, high numbers of orphans due to HIV/AIDS, limited resources for expansion of universities to cope with the number of students leaving secondary schools, mismatch between the skills offered by the university and the demand of the labor market as well as the high ratio of pupils to teachers in some parts of the country (Mukhwana 2016).

This paper examines how the Taia Leo newspaper in Kenya is useful as a tool for instruction and of reference to teachers and students in the institutions of learning, especially at high school level. It is all about how the newspaper can be used in the classroom for teaching and learning of Kiswahili language grammar. A newspaper is a cheap way to enhance class work by providing the basics for studying different subjects from basic literacy to the highest level of critical thinking (Wheeler and Wheeler 1945).

Presently, most teachers the world over are using newspaper during the teaching process of their subjects. This has made learning more enjoyable and realistic because some issues which are not found in the textbooks can be found in newspapers. On the other hand, most students spent much of their time reviewing newspapers during their free times or during the library lessons. Reading 
newspapers helps students to be updated with the current events as well as benefiting them academically.

This research focuses on the contents and texts of the Taifa Leo newspaper which are likely to have the value of being used in the classroom to teach about Kiswahili grammar. Being easily available and frequently used in most schools in Kenya, it is a matter of concern to find out whether the use of the Taifa Leo newspaper is significant in relation to the Kenyan formal education or not. When used well and effectively to serve the educational purposes, the newspaper can be of great importance in education.

The newspaper has in the recent years been deeply involved in the field of education through the Newspaper in Education (NIE) project which was initiated by the Nation Media Group in conjunction with the Safaricom foundation and the KCB foundation whose aim is supporting education and developing young analytical readers through exposing them to the real world outside the classroom through the highly updated reference book, "'the newspaper."

The project intents to incorporate the newspaper in the education system in order to make students informed on the issues happening in their society and on important matters of their interests that might not be found in the textbooks on academic subjects such as such as science, geography as well as reinforcement of the basic living skills of the students. The Nation Media Group has been responsible for the distribution of Taifa Leo newspapers in some schools in the country as a way of ensuring that the newspapers are available and used by the teachers and students in learning. Through the NIE program, the newspaper is helping in the improving of the education in Kenya by the use of the newspaper to help the students to understand the importance of the school curriculum.

This paper therefore aims at finding out the relevance of Kenya's Taifa Leo newspaper in the education of the students at the secondary school level, especially by focusing on the teaching and learning of Kiswahili language grammar.

The use of the newspaper in education in Kenya is being pushed and supported by different institutions in the country but there is no enough knowledge on how suitable the Kenyan newspapers are in relation to the teaching and learning of Kiswahili language grammar.

Even though much has been done and written on the educational function of the newspaper, not much has been done in relation to this topic in Kenya. Newspapers in Education being a new initiative in Kenya, this study aimed at adding a body of knowledge in the field of education in relation to the newspapers' use for teaching and learning.

This paper will try to inspire teachers to use the newspapers as a teaching resource besides challenging the publishers of the newspapers to keenly and properly edit the newspaper contents to make sure that published newspapers do not have a lot of errors so as to fulfill the teachers' and learners' needs during learning.

\section{GOAL AND OBJECTIVES OF THE STUDY}

Goal: The main goal of this study was to investigate the extent to which Taifa Leo newspaper in Kenya are used for Kiswahili language instruction of high school students by focusing on the contents and texts of Taifa Leo newspaper.

\subsection{Specific Objectives}

This study aimed at assessing the use of Taifa Leo newspaper in teaching about Kiswahili language grammar in the Kenyan secondary schools.

This study sought to achieve the following objectives;

- To find out whether the contents of Taifa Leo newspaper in Kenya are suitable to be used for teaching and learning of Kiswahili language grammar in Kenya's secondary schools.

- To determine how the newspaper is used as an instruction tool in Kenyan secondary schools in relation to Kiswahili language grammar teaching and learning. 


\section{JUSTIFICATION OF THE STUDY}

The newspaper is an informational tool for educational and personal empowerment. When students use the newspapers, it helps them to do away with the dependency on others for information. This way, students are made independent and self reliant seekers, gatherers and interpreters of information. Therefore, the newspaper can facilitate the development of skills through both an intellectual and personal empowerment process.

By reading the newspaper, students are capable of getting global information, which is important to them because of the global interdependence of the world economy as well as social and political infrastructures, therefore, learners need to get information on their national and global affairs and because most students do not spend much time discussing about the international affairs, the national newspaper is seen to be the best source for such information and it has a role of moving its readers beyond localism and regionalism to a great sense of international awareness. The newspaper is found to have more complete news as compared to the news on the television.

Using the newspaper in the classroom helps to promote critical thinking among the learners by exposing the students to the stimulating information from which probing questions can be asked and if they are provided examples of critical thinking as manifested in the newspaper. This skill also, is developed by exposure to a blend and balance of widely differing opinions that are most likely to be found only in the national newspapers.

Also, if used, the newspapers do help the students to develop vocabulary in different languages. The national newspapers use the vocabulary that assumes a more intelligent, educated, professional and influential readership as compared to the level of writing with the word choice in many local newspapers.

By reading the newspaper, the learners are capable of releasing emotional tension and also able to overcome loneliness. Entertainment news like cartoons and television highlights that are printed in the newspaper, could overcome the feelings of boredom and the learners' stressful life.

According to Gardner, J.N and Sullivan, B.L (2004), the Newspaper in Education has the following benefits;

- The initiative helps in the sharpening of students' thinking skills as well as boosting their interests and motivation in different subjects by ensuring that study materials relevant to their lives, are provided.

- Through the Newspaper in Education program, students are prepared for active citizenship of their countries.

- It helps in heightening the teachers' interests in the new techniques of teaching.

- It helps in improving the relationship between the students and their communities as they are fed on the information about their communities, therefore, they are able to know much about their community. This way, public and community relations are improved.

- The Newspaper in Education has led to long term newspapers' readership.

- Also, the program has made the newspaper to be recognized as an important tool for continuing education for community members who are no longer in the classroom.

\section{RESEARCH METHODS}

In this study, the researchers applied qualitative research methods.

\subsection{Content/ Text Analysis}

Content analysis is a technique for systematically describing written, spoken or visual communication. This may include media print, (newspapers, magazines), television, radio, movies and the internet among others. By using this method, the researcher will focus on the texts in the Standard and Taifa Leo editions of between January $27^{\text {th }} 2016$ and April 2016, to find out how they can be used in teaching different aspects of Kiswahili and English language grammar by focusing on different texts purposively selected by the researcher. The newspapers were selected for this period 
because during the period, students are in schools and the researcher believed that the contents of the newspaper will greatly relate to the academic needs of learners.

The researchers then categorized data in different classes of grammar based on the researcher's own interpretation. Based on the classified data, the researchers then draw conclusions and report findings of the study.

\subsection{Survey}

This was be done mainly through the questionnaires and the use of interviews. The researcher will send questionnaires to the correspondents through the email. This will be fair and cheap for the researcher in relation to the distance and cost. Also, this will allow the correspondents to fill them at their own convenience.

In addition, the researchers used telephone interviews in gathering the information. Personal interviews allowed for some personal conducts between the interviewers and the respondents and therefore, the researchers were able to ask follow up questions.

By combining the two research methods, the evaluation of the researchers' findings were improved by ensuring that the limitations of one type of method are balanced by the other. The researcher employed sequential data gathering technique, whereby, they gathered one type of data first, and then used it to collect the other type of data. Data collection was done independently and then combined at the end for interpretations and conclusions.

\subsection{Research Design}

By using both the survey and the qualitative content analysis research, the researcher were able to gain much understanding of the topic and support for their findings by one method covering up for the weaknesses of the other. For instance, the content analysis research helped in describing the newspaper content which can be used to teach different aspects language. On the other hand, the survey helped in gathering information from teacher respondents on how the newspaper is used to teach Kiswahili grammar in Kenya's secondary schools. Combining these methods helped in dealing with the weaknesses of each of these research methods.

In this study, qualitative content analysis helped in the provision of knowledge about the Taifa Leo newspaper and the newspaper's contents in relation to education and then the study of those variables with a limited sample of individuals was done using a survey. This way, the researchers were able to gather the required data from both the source and the population.

\subsection{Target Population}

The target population for this research included Taifa Leo newspaper for the period of three months, and 20Kiswahili language secondary school teachers selected randomly from different secondary schools in Kenya.

\subsection{Sampling Size and Techniques}

In this study, the researchers employed non probability sampling techniques which mainly included purposive sampling. By using purposive sampling, the researchers were able to quickly and easily reach their target sample. Under this technique, the researchers focused on the non-proportional quota sampling, which is less restrictive and therefore, the researchers only had to specify the minimum number sampled units in each category. This technique was used in the selection of Taifa Leo newspaper for content analysis, Taifa Leo, being the only serious Kiswahili newspaper in Kenya, was sampled.

Also, snowball sampling technique was used in carrying out a survey which involved secondary school teachers in Kenya on the use of the newspaper as an instructional tool for teaching and learning. In snowball sampling, researchers will identify someone who meets the criteria for inclusion in their study. Researchers asked them to recommend others who they knew, who also meet the criteria. Being impossible for the researchers to reach the target population back in Kenya, snowball sampling technique was of relevance to this study. 


\subsection{Data Collection Tools and Techniques}

Data collection involves conducting members of the population that will be sampled, in order to obtain correct information about a study.For this study, data was collected through the content analysis of the Kiswahili newspaper in Kenya, theTaifa Leo for the period of between January and April 2016. Also, data was collected from Kiswahili language teachers about their opinions, behavior and knowledge on the use of the newspaper as ateaching tool in Kenya secondary schools through questionnaires and telephone interviews. The researchers benefited from the help of a research assistant who played a great role in the subscription of the online newspaper and collection of data for analysis.

\subsection{Data Analysis and Presentation}

In this study, the collected data was analyzed by using the open coding, which is the technique that involves the breaking down, examining, comparing and categorizing data. This helped the researchers in the classification and categorization of data, and which made it easy for the researchers to discover patterns and draw conclusions.

\section{DATA ANALYSIS AND Discussion OF FINDINGS}

In this section of the paper, data analysis, presentation and interpretation was dealt with in relation to the research objectives of the paper..Data is analyzed descriptively, and this involved reviewing and summarizing the data collected through the content analysis of the Taifa Leonews paper as well as the recorded interviews and the received emails, to obtain the required data in relation to the research objectives.

The Taifa Leo newspaper in Kenya can be regarded as a kind of educational resource for teaching Kiswahili language because it contains words, phrases and clauses which follow grammatical rules and structures.

\subsection{The Taifa Leo Newspaper Content/Text Analysis.}

The content analysis of the Taifa Leo newspaper was done by purposively selecting texts and phrases from the randomly selected pages of the paper. The researchers coded different units of grammar that they wanted to find out from the newspaper texts. The units that the researchers used included; phrases, paragraphs, sentences as well as single words, which they put in different categories (codes). Formulating categories is the heart of content analysis. Different aspects were categorized independently to make sure that each category is not affected by the other. To check for reliability, the researchers compared the way independent coders have coded different items, they later compared their coding decisions and determined the extent to which they agree. The researchers later checked through to prove the validity of the results and reported the results as shown below.

As a Kenyan national newspaper, Taifa Leo plays a significant role in the education of its readers based on its contents. This is seen from the punctuation of the articles from which the students can learn from, grammar, literature, samples of national exam questions in different subjects and their marking schemes, composition writing and other topics relevant to other subjects as well as keeping the learners informed on what happens around them. In this paper, the researchers focus on how the newspaper is relevant in the teaching of Kiswahili grammar.

Grammar is the set of structural rules that govern the composition of clauses, phrases and words in any given language. Grammar consists of sounds, word structures and meaning. Taifa Leo newspaper can be used in the teaching of Kiswahili grammar as follows:-

\subsection{Semantics}

Semantics refers to the branch of linguistics and logic concerned with the meaning of a word, phrase, sentence or a text. One of the articles in the Taifa Leo issue of 27th January talked about the semantic changes. Semantic changes involve changes in the meanings of words of a certain language. Put in Kiswahili language: Mabadilikoyakisemantikiyanahusu kubadilika Kwa maana za maneno katika lugha. Further, in this article, it is further explained that semantic changes such as meaning expansion, is about weakening the meaning of a word. The changes that occur on the meanings of a word is a normal unusual procedure that is accepted by the speech community of the specific language in question. 
Normally, changes in meanings of different words in a language do follow a certain procedure. This article in point showed three ways of how changes occur in Swahili language as shown.

\subsubsection{Shifting of the Meaning/Kubadilika Kimaana}

This involves the changing of the meaning of a word as time goes by. The article shows several Swahili words whose meanings have shifted. Some of the examples given include;

- Zingua-this word earlier meant the act of saving somebody from danger or difficulty. Kitendo cha kumtoa mtu katika hatari au shida.

Later, the meaning of the above word changed to mean, "Causing trouble or danger to someone.' '(Kumweka mtu katika hatari au matatizo.)

- Demu- Earlier, the word used to mean rags/ torn clothes. (Nguo mbovu iliyochanika.)

Now, the word means, a girl/lady. (msichana)

- Mzee wa busara- Used to mean, a wise man, especially of old age. ( Mtu mwenye umri mkubwa na mwenye hekima)

Now, the term means, a witch. (Mchawi)

\subsubsection{Adding an Extra Meaning to Words.(Kuongeza Maana)}

These changes occur when a word gets extra new meanings. In Swahili, there are many words which have got new meanings due to changes in time. For example;

- Shoga-Female friends.(marafiki wa kike) has added another meaning to mean, "A homosexual/gay." (Mwanamume anayeingiwa na mwanamume mwingine kinyume na maumbile).

- Chimbo- A hole/mine. Shimo kubwa ambalo limechimbuliwa

- As time has passed, the word has gained an extra meaning to also mean, " A hiding place." (Mahali ambapo mtu amejificha)

- Mshenzi- Originally meant, a stupid, marnerles individual. Mtu asiye na adabu.

- Presently, the word also means, an expert in a certain field. Mahiri wa kufanya jambo Fulani.

\subsubsection{Fading of the Meaning/ Kudhoofika Kwa Maana.}

As stated in the article, these are semantic changes that involve the fading of the meaning of certain words which were used in the past or a new meaning was introduced to a word in the present times. In Swahili language for example, there are different words whose meanings have faded and instead, the new meanings created are now mostly used. The articles gives the following examples.

- Mteja- The original meaning which meant " a merchant/seller of certain commodities." (Mtu anayeuza bidhaa Fulani). Now the term means," a drug addict" (Mtu atumiaye dawa za kulevya).

- Mzee wa busara- Initially, the term used to mean " a witch" (Mchawi) but after the meaning faded, it now means ' a wise man of old age.' (Mtu mwenye umri mkubwa na mwenye hekima)

\subsection{Swahili noun classes/ Ngeli za Kiswahili}

In the Taifa Leo issue of $19^{\text {th }}$ February 2016, there is information about the Swahili noun classes. The noun class refers to the systematic grammatical knowledge that enables one to place different nouns in different groups.

The Swahili noun classes which are discussed in this issue include; A-WA, KI-VI, U-U, U-YA, KI-VI, $L I-Y A, Y A-Y A, K U-K U$ as well as $M U$.

Nouns in Kiswahili are put in different classes based on the following characteristics

\subsubsection{Classification Based on the Prefix/Kwa Kutegemea Kiambishi Awali.}

By focusing on the prefix of a noun, most pronouns with, "KI' as their prefix are put in the class of 'KI-VI'" The living things are put in class A-WA, which has the names of individuals, animals, fish and insects. Katika ngeli hii kuna nomino za watu, ndege, wanyama, samaki na wadudu. 


\subsubsection{Classification based on the smallness of the noun/kwa kuzingatia udogo wa nomino.}

based on the smallness of the noun, we have the prefix "KI" in singular and "VI" in plural. That's why we have kijitu meaning a small person in singular, and vijitu in plural. This way, adjective renders used are different from those used in the noun class of A-WA by use of hiki, kileand hivi, vile in plural. In noun classes of U-ZI, on the part of U, there are different types of nouns which changes differently when it comes to their plural. The prefix of this noun class is $U$ and WA but in plural, the prefix might be $\mathrm{Ny}-, \mathrm{Mb}-, \mathrm{Ny}-, \mathrm{Nj}^{-}$, and also by ejecting the prefix $\mathrm{U}$, as shown in the examples below;

\section{Singular}

- Uta wa msasi

- Ubao mdogo

- Udevu mrefu

- $\underline{\text { Usiku ule }}$

\section{Plural}

Nyuta za wasasi

Mbao ndogo

Ndevu ndefu

_siku zile

\subsubsection{Classification based on the Plural of the of the Classes/Kwa Kuzingatia Wingi Wa Ngeli}

In the U-ZI noun class, we have nouns whose prefix in singular are "'W' and 'Ny' in plural, as shown in;

Wimbo singular and Nyimbo plural meaning," a song in singular and songs in plural.

Taifa Leo, February $19^{\text {th }} 2016$ pg 20

\subsection{Punctuation}

Punctuation is the practice or system of using certain conventional marks or characteristics in writing or printing in order to separate elements and make their meaning more clear, by showing end of sentences, separation of clauses or sentences.

The articles in the Taifa Leo newspaper are well punctuated and can therefore be used for reference when teaching and learning about punctuation marks in the classroom. As in the following text;

\section{WABUNGE WATAKA 2B BILA JASHO}

Wabunge wanapanga kujilipa zaidi ya Sh2 bilioni ili wafidie miezi minane ambapo hawatakuwa bungeni, baada ya uchaguzi Mkuu wa Agosti 8, 2017.Wanasema kisheria wanapaswa kuhudumu kwa miaka mitano kamili, na muda wao unapaswa kukamilika Machi 2018 na wala sio Agosti 2017.Kila mbunge, ambao kwa jumla ni 390, hupokea mshahara wa chini wa Sh.740,920 kwa mwezi huku wenzao maseneta wakilipwa Sh. 740,929 kila mmoja.Viongozi wa bunge wameidhinisha pendekezo la baadhi ya wabunge wanaohisi kwamba, kwa sababu bunge la sasa ni la mpito na halijatimiza miaka mitano, wanastahili kulipwa.

In the above article which talks about the members of parliament planning to pay themselves Sh. 2 billion for the time they will not be in office after the General Elections in August 2017, we can see that each of the four sentences starts with a capital letter; Wabunge, Wanasema, Kilambunge and Viongozi. Capital letters have also been well used at the beginning of the names of months such as Agosti and Machi. Also, commas have been used appropriately to show where the reader can stop and rest and also in numbers such as, Agosti 8, 2017 to separate the date from the month/year as well as in currency Sh.740,920 and 740,929. Full stops have been used appropriately to mark the end of sentences as well as in the shortening of words such as shilingi, to be Sh. Which start with a capital letter. Taifa Leo February 22, 2016, page 1.

\subsection{Tense and Aspects}

Tense is the time of the verbs' action or state of either being present, past or future. Aspects are actions just completed and the continuous or progressive ones.

\subsubsection{Present Tense}

Is marked by using 'na' as a prefix on the verb. By selecting different sentences and texts from the Taifa Leo newspaper, the teachers can use them to teach this tense. From the analyzed papers, the following examples were picked. 
- Maelfuyaraiawa Sudan waliotoroka mapiganokatika eneo la Jebel Marra, ukanda wa Darfur baina ya majeshi na waasi, wanahitaji msaada wa dharura wa kibinadamu. Umoja wa mataifa $(U N)$ ulisema Jumapili.(Thousands of Sudanese who fled from the fights that arose in Jebel Marra, in Darfur between the military and the rebels; need the emergency humanitarian aid, the United Nations said on Sunday). Taifa Leo, February 18,2016 page 1.

- kampuni ya M-KOPA inayouza vidubwasha vitumiavyomiale ya jua sasa imezindua televisheni ya kidijitali itakayotumia nguvu za jua kujiendesha. (The M-KOPA company which sells solar items, has invented a digital television that will use solar energy to operate).

\subsubsection{The Future Tense}

The verbs in this tense have ''ta'" as a prefix. The tense shows that something is expected to happen. Some of the sentences in the Taifa Leo newspaper show this and the selected examples include,

- Takribanwapigakuramilioni 15 watashiriki uchaguzi mkuu wa Uganda huku tume ya uchaguzi nchini humo.... (Approximately 15 million voters will participate in the general elections in Uganda as the electoral commission in the country...) Taifa Leo, February 18,2016 page 13.

- Katika uchaguzi wa leo wagombeaji saba watamenyana na kigogo...(In today's election, seven presidential candidates will contest against the veteran....) Taifa Leo, February 18,2016 page 13.

\subsubsection{Past Tense/Wakati Uliopita}

It is used to refer to an action that has already taken place, the prefix ' $l i$ '" is added to the verb. Selected examples include;

- Watuwawilijanawaliokolewa wakiwa hai kutoka kwa vifusi vya jumba moja la makazi, zaidi ya masaa 50 baada ya kuporomoshwa na tetemeko kubwa. (Two people were saved yesterday from the debris of one of the residential buildings after more than 50 hours after the building was brought down by a great earth quake. Taifa Leo, February 9 th 2016 page 14.

- Kinara wa Cord Raila Odinga jana alisema haifai kwa wakenya kuendelea kuwekwa gizani kuhusiana na idadi ya wanajeshi waliouawa na wapiganaji wa kundi la Alshabaab. ( Cord leader Raila Odinga yesterday said that it is not good for Kenyans to still be kept in darkness about the number of the military officers who were killed by the Alshabaab fighters). Taifa Leo,18th February 2016 page

\subsubsection{Just Completed/ Hali Timilifu}

In Swahili, this aspect is represented by the use of the prefix ' $m \boldsymbol{e}$ '.'the following examples were extracted from the selected Taifa Leo texts.

- Kiongoziwa Cord Raila Odinga, amemwambia mwenyekiti wa Benki Kuu ya Kenya (CBK) Muhamed Nyaoga kwamba..... ( The Cord leader Raila Odinga has told the chairperson of the Central Bank of Kenya( CBK) Muhamed Nyaoga that....) Taifa Leo, January $26^{\text {th }} 2016$ page 2.

- Hakimu mmoja katika mahakama ya Narok amelalamikia idadi kubwa ya kesi zinazohusu unajisi katika mahakama yake. ( A judge at Narok law courts has complained about the increased cases on rape in his court) Taifa Leo, January $20^{\text {th }} 2016$.

\subsubsection{Continous/ Habitual aspect}

The progressive or habitual aspect refers to the actions that do occur continually or as a habit. In Swahili, the prefix ' ' $h \boldsymbol{u}$ '" is added to the verb. As shown in the examples bellow.

- Wafungwahukirimakosawasiotendaili kuhepa rumande.... (prisoners always admit having done the wrongs they never did in order to escape being remanded). Taifa Leo, February 192016 page 8 .

- Munya ajue mbwa humbwekea chui ila mwishowe hugeuzwa mlo. ( Munya should know that a dog barks at a leopard but at last it is turned into a meal). Taifa Leo, January 312016

\section{CONCLUSIONS}

Kenya's Taifa Leo newspaper is an essential reference material in the teaching of different aspects of Kiswahili language grammar in Kenya secondary schools. Despite making students to actively 
participate and enjoy during the teaching-learning process, learners also gain skills to critically analyze and create meaning from different Taifa Leo newspaper articles. Furthermore, students gain skills to search for Taifa Leo online newspaper on the internet using their computers during the teaching/ learning process. This way, students develop media literacy skills. In addition, students become independent learners as they are able to search for information online and also, interpersonal relations between and among students are built as teachers encourage them to work together.

By accessing online learning network sites, the use of the newspaper in teaching is made more effective as teachers can get reliable and valid information and guidance on areas they get difficulties when using the newspaper as a reference tool.

Even though the newspaper texts are of relevance when it comes to the teaching of language grammar in Kenya's secondary schools; some newspaper texts are poorly edited by journalists who lack relevant editing skills. Such texts, when used in the classroom by teachers to teach different aspects of language grammar, may cause difficulties and confusion to both the teacher and the students. The researchers therefore recommend that future research should be done on how language is improperly used in Kenya's Taifa Leo newspaper, making it not suitable as an instructional tool.

\section{REFERENCES}

[1] Cabansag, J.N (2011-) The Role of Mass Media in the Development of English Language Skills among AB English Students of Isabela State University. 82 - 98.

[2] Gardner, J.N and Sullivan, B.L. (2004) The National Newspaper a tool for Educational Empowerment: Origins and rationale. College.Monograph.http://www.nytimes.com/ref/college/faculty/coll_gard.htm. Retrieved on 23/11/2015, 9:22pm.

[3] Mukhwana, C.S (2016) An Inquiry into the Role of Kenya's Mainstream newspaper as a Teaching Learning Resource for Kiswahili and English Language Grammar in Kenya's Secondary Schools. Unpublished M.A Thesis, Communications University of China.

[4] Njeze, M.E. (2013) Use of Newspapers and Magazines in the Academic pursuit of University Students: Case Study of Covenant University. http://www.digitalcommons.unl.edu.cgi. Retrieved on 23/11/2015, $8: 53 \mathrm{pm}$.

[5] Veronis (2005) Newspapers, Magazines face challenges in the Internet Age but will survive: In Media Post Publications, Media post news..

[6] Wheeler, I.R and Wheeler, V.D (1945) Newspapers in the classroom.The Elementary English Review 22(8), Pp. 324 - 329. http://www.jstor.org/stable/41383400. retrieved on 2/12/2015, 6pm.

\section{AUTHOR'S BIOGRAPHY:}

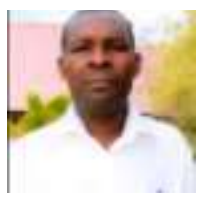

Mukhwana, A. Sirengo, PhD in Linguistics, is a Senior Lecturer in the Department of Kiswahili, University of Nairobi where he teaches Sociolinguistics and Communication. He has published extensively both nationally and internationally besides attending many conferences nationally, regionally and internationally.

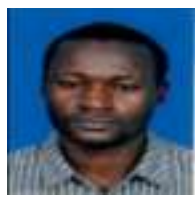

Mukhwana, C. Sirengo is a former teacher of Kiswahili and History at Shimo la Tewa High School in Mombasa, Kenya. He holds a Bachelor of Education degree from the University of Nairobi in Kenya and a Master of Arts degree in Communication from the Communication University of China in Beijing.

Citation: Mukhwana A. Sirengo, Mukhwana C. Sirengo. "The Role of Kenya's Taifa Leo Newspaper in Enhencing Learners' Abilities in Kiswahili Language Proficience" International Journal of Humanities Social Sciences and Education (IJHSSE), vol 4, no. 12, 2017, pp. 53-61. doi: http://dx.doi.org/10.20431/23490381.0412007.

Copyright: (C) 2017 Authors. This is an open-access article distributed under the terms of the Creative Commons Attribution License, which permits unrestricted use, distribution, and reproduction in any medium, provided the original author and source are credited. 